\title{
Perancangan Buku Ilustrasi “Just Do (Odle) It!”
}

\author{
Ade Kartika Effendi ${ }^{1)}$, Aji Windu Viatra ${ }^{2)}$, Husni Mubarat ${ }^{3)}$ \\ ${ }^{1) 23)}$ Program Studi Desain Komunikasi Visual Fakultas Ilmu Pemerintahan dan Budaya \\ Universitas Indo Global Mandiri \\ Jl. Jend Sudirman No. 629 KM.4 Palembang Kode Pos 30129 \\ Email : $\underline{\text { adekartikaef@gmail.com }}{ }^{1)}, \underline{\text { aji_dkv@uigm.ac.id }}{ }^{2)}, \underline{\text { husni_dkv@uigm.ac.id }}^{3)}$
}

\begin{abstract}
Doodle is an activity that anyone can do it. This scribbling/doodling activity is often referred to as doodle. Lots of people who knowingly or unknowingly ever made a doodle. Doodle can be a beautiful work of art and bring the benefits to those who diligently it. But there is a problem for the doodle maker, it's the artwork that usually does not have character. That's because lack of information and knowledge about Doodle. Books about doodles are widely circulating in the market, but the problem is the Information \& Knowlegde of Doodle Books stiil not available yet. Therefore an Illustration Book Design "Just Do(odle) it!" was created which aims to introduce and provide information and knowledge about doodle for the wider society.
\end{abstract}

Keywords : Doodle, Design of Doodle Illustration Book, Media Promotion

\begin{abstract}
Abstrak
Mencoret adalah sebuah kegiatan yang bisa dilakukan oleh siapapun. Kegiatan mencoret ini sering disebut juga dengan "doodle". Banyak sekali orang yang secara sadar ataupun tidak pernah membuat doodle. Doodle dapat menjadi sebuah bentuk karya seni yang indah dan mendatangkan keuntungan bagi yang menekuninya. Tetapi ada problema yang sebenarnya terdapat pada pembuat doodle yaitu karya yang biasanya tidak memiliki karakter, hal ini dikarenakan kurangnya informasi dan pengetahuan tentang doodle. Buku tentang doodle banyak beredar di pasaran, namun permasalahan yang dimiliki adalah belum adanya buku doodle yang memuat sejumlah informasi dan pengetahuan, oleh karena itu dibuatlah Perancangan Buku Ilustrasi “Just Do(odle) It!” yang bertujuan untuk mengenalkan serta memberikan informasi dan pengetahuan tentang doodle kepada masyarakat luas.
\end{abstract}

Kata kunci : Doodle, Perancangan Buku Ilustrasi Doodle, Media Promosi 


\section{Pendahuluan}

Karya seni adalah hasil dari proses analisa data, perasaan dan imajinasi seseorang atau lebih. Karya seni biasanya hanya bertujuan untuk mewakili perasaan dan imajinasi, berbeda dengan karya desain yang tujuan utamanya adalah bisa berkomunikasi dengan target sasaran yang telah ditentukan. Banyak sekali faktor yang dapat memicu lahirnya sebuah ide untuk memulai proses berkesenian. Kejenuhan dan kebosanan dapat memicu seseorang menciptakan sebuah karya seni yang abstrak namun terkesan indah dan bermakna, meggunakan teknik menggambar freehand (bebas semaunya) serta tidak beraturan. Karya seni semacam itu biasanya disebut dengan doodle.

Menurut Piaget dalam Jayanti, 2013 'doodle jika diartikan secara harfiah ke bahasa Indonesia berarti "mencoret". Mencoret merupakan hal paling gampang dan mudah dilakukan, dengan media untuk menulis, seperti kertas, pulpen dan pensil, kita dapat menghasilkan sebuah coretan. Kegiatan "mencoret" seperti ini juga sering disebut dengan doodling bentuk abstrak.

Setelah melakukan observasi di toko buku, penulis belum menemukan buku yang memiliki nilai-nilai edukasi, tutorial dan sejumlah info lainnya mengenai doodle. Poin penting seperti sejarah, pemahaman, tips, trik dan tutorial doodle tidak dimuat dalam buku doodle yang diproduksi di pasaran. Di sisi lain, fenomena terbitnya sejumlah buku doodle di pasaran memang sangat menakjubkan, hal ini menunjukkan bahwa semakin banyak doodlers yang mampu membuat doodle. Kekurangan dari buku-buku tersebut adalah minimnya informasi dan pengetahuan di dalamnya. Isinya juga hanya menggiring sejumlah konsumen untuk mewarnai bidang polos saja, memberi warna sejumlah doodle yang sudah disediakan, tidak menuntun seseorang untuk menciptakan doodle yang berkarakter. Dampaknya adalah sebagian orang akhirnya tertarik dengan doodle dan memulai untuk membuatnya, namun tidak memiliki karakter karena bergantung pada doodle-doodle terdahulu saja. Sebagian lagi mungkin merasa ragu untuk memulainya, karena tidak memiliki info dan pengarahan yang jelas.

Dalam kurun waktu 2016-2018, mulai terdapat denyut yang cukup kencang di dunia doodle, sejumlah penggiat doodle sudah mulai berjejaring satu sama lain, bahkan sebagian doodlers sendiri sudah ada yang serius menekuni dan menghidupi doodlenya. Namun, hal tersebut tidak serta merta menihilkan permasalahan yang ada, sejumlah masalah kerap dijumpai. Permasalahan yang sering dijumpai diantaranya adalah gejolak dan semangat doodlers yang pasang surut serta minimnya doodlers yang memiliki karakter dalam berkarya.

Berdasarkan permasalahan yang dijelaskan sebelumnya, maka penulis terinspirasi untuk merancang sebuah buku ilustrasi berjudul "Just Do(odle) It!". Perancangan ini bertujuan untuk mengomunikasikan pada masyarakat terutama target sasaran bahwa sebenarnya doodle memang dapat dibuat oleh siapa saja secara serius ataupun hanya sebagai pengisi waktu luang. Selain itu buku ini akan menegaskan juga bahwa doodle bukan hanya pekerjaan yang sia-sia, karena selain indah, jika dikerjakan secara serius (baik teknik dan konsep), doodle akan meningkatkan kreatifitas, produktivitas serta menghasilkan pendapatan ekonomi yang menjanjikan.

Rumusan masalah dari perancangan ini adalah bagaimana merancang buku ilustrasi "Just Do(odle) It!" yang memuat sejumlah informasi dan pengetahuan tentang doodle serta bagaimana merancang buku ilustrasi dengan komposisi yang menarik.

Adapun tujuan dari perancangan buku ilustrasi "Just Do(odle) It!' yaitu menambah wawasan masyarakat tentang doodle, mulai dari sejarah, pemahaman, tips, trik dan tutorial, mendorong minat baca melalui buku ilustrasi yang menarik dan informative serta menambah sumber literasi untuk masyarakat tentang doodle.

Penulis memilih beberapa metode untuk mengumpulkan sejumalah data primer melalui observasi, wawancara dan dokumentasi. Pengumpulan data sekunder merupakan pencarian data secara tidak langsung yaitu menggunakan perantara seperti media berupa buku, arsip, internet, baik yang dipublikasikan maupun tidak.

\section{A. Landasan Teori}

1. Desain Komunikasi Visual

Desain Komunikasi Visual merupakan seni dalam menyampaikan informasi atau pesan dengan menggunakan bahasa rupa/visual yang disampaikan melalui media berupa desain. Desain Koumunikasi Visual bertujuan menginformasikan, mempengaruhi hingga mengubah perilaku target sasaran sesuai dengan tujuan yang ingin diwujudkan. Proses desain pada umumnya memperhitungkan aspek fungsi, estetik dan berbagai aspek lainnya yang biasanya datanya didapatkan dari riset, pemikiran, brainstorming maupun dari desain yang sudah ada sebelumnya (Anggraini Lia S \& Nathalia Kirana: 2014: 15)

Perancangan ini menggunakan ilmu DKV untuk menghasilkan media utama dan media pendukung. Seperti yang sudah dilihat dari penjabaran di atas ada beberepa aspek yang diperlukan dalam proses desain seperti aspek fungsi, estetik dan beberapa aspek lainnya. Ada aspek lain yang tentu tidak kalah pentingnya bahkan menjadi sebuah pondasi untuk memulai proses desain yaitu unsur-unsur pada desain. Berikut akan diterangkan secara singkat ke-6 unsur-unsur desain.

a. Garis (Line)

Garis dihasilkan dari satu titik poin ke titik poin lainnya, dapat berbentuk lengkung (curve), lurus (straight), putus-putus, zig zag, meliuk-liuk hingga garis tidak beraturan. Untuk membangun sebuah bidang diperlukan garis sebagai unsrunya. Ada bermacam fungsi garis lainnya, diantaranya dapat menimbulkan citra dan sebagai sebuah pertanda. Dalam ilmu desain garis digunakan sebagai alat untuk memperjelas dan mempermudah pembaca. 


\section{b. Bentuk (Shape)}

Segala sesuatu yang memiliki diameter, tinggi dan lebar merupakan sebuah bentuk. Bentuk-bentuk dasar yang sering digunakan adalah kotak,lingkaran, segitiga, lonjong dan lain-lain. Berdasrkan sifat bentuk dibedakan menjadi 3 yaitu bentuk geometri, natural dan abstrak.

c. Tekstur (Texture)

Tekstur merupakan tampilan luar yang dapat dilihat dan diraba dari suatu benda. Tidak semua tekstur berbentuk nyata, di dalam ilmu desain terdapat tekstur semu yang dibuat secara visual melalui sebuah bidang, tujuannya adalah untuk mengatur keseimbangan (balance) pada sebuah desain.

d. Kontras (Contrast)

Yang dimakusud dengan kontras adalah penentuan gelap dan terang yang tentunya berlawanan dan memiliki perbedaan terhadap warna dan titik fokus. Fungsi kontras dalam penerapan ilmu desain adalah untuk menonjolkan sebuah pesan dan menimbulkan kesan dramatis. Dengan penyusunan komposisi kontras yang pas maka dapat menghasilkan sebuah desain yang memiliki tingkat keterbacaan, fokus dan titik berat suatu desain semakin bertambah.

e. Ukuran (Size)

Besar kecilnya objek dapat dikatakan sebagai ukuran. Ukuran membantu desain menjadi kontras dan tentunya akan menimbulkan sebuah penekanan (emphasis) pada objek desain. Peran ukuran adalah sangat besar terutama untuk membentuk sebuah hirarki pada desain yang dihasilkan, seperti mana yang sangat penting, kurang penting dan tidak penting pada sebuah karya desain.

f. Warna (Color)

Warna dapat menampilkan sebuah citra dan identitas pada sebuah desain. Pengaturan warna dalam ilmu desain sangat penting karena dapat mempengaruhi cara kerja desain yang akan dihasilkan. Agar warna dapat tersusun secara harmonis maka dikategorikan menjadi 4 jenis yaitu warna primer, warna sekunder, warna tersier dan warna netral. Warna primer diantaranya adalah merah biru dan kuning. Warna sekunder adalah pencampuran warna-primer dengan proposi 1:1 sedangkan warna tersier adalah campuran warna primer dengan salah satu warna sekunder. Warna netral adalah pencampuran dari ketiga warna sebelumnya dengan perbandingan 1:1:1, biasanya warna ini berfungsi untuk menimbulkan kesan kontras. Kemudian terdapat dua jenis perbedaan warna yaitu warna yang ditimbulkan karena sinar (Adjective Color/RGB) dan warna yang dittimbulkan karena tinta atau cat (Substractive Color/CMYK).

\section{Estetika}

Sebagai cabang filsafat, estetika menjabarkan anatomi gagasan tentang kesenian sehingga ragam gagasan seni dapat terpetakan mulai dari asumsi hingga implikasinya. Dengan membantu memetakan strtuktur gagasan kesenian, estetika tak hanya berguna pada kritikus seni tetapi juga bagi para seniman dalam kerja keseniannya (Suryajaya, 2016: 8).

Berdasarkan kutipan diatas dapat ditarik sebuah kesimpulan bahwa dalam proses melakukan kerja seni ternyata estetika tidak hanya sebatas menerangkan embel-embel keindahan saja, melainkan sebuah kesatuan gagasan seniman untuk memuat karyanya mulai asumsi hingga hasil penelitiannya. Ada sebuah proses yang secara sadar maupun tidak sadar telah dikerjakan oleh para seniman untuk menghasilkan karyanya yaitu memikirkan nilai estetis, pengalaman estetis dan sebuah karya seni yang bersifat konkret serta hubungan seni dengan masyarakat tertentu.

Agar perancangan ini menjadi menarik perhatian dan tepat sasaran, maka berbagai elemen-elemen yang digunakan dalam menyusun perancangan ini menggunakan pendekatan estetika.

Keindahan dan rasa seni dibutuhkan dalam perancangan buku ini, karena keindahan mampu menjadi daya tarik dan sangat mempengaruhi psikologi seseorang.

3. Ilustrasi

Ilustrasi secara harfiah berarti gambar yang dipergunakan untuk menerangkan atau mengisi sesuatu. Dalam desain grafis, Ilustrasi merupakan subjek tersendiri yang memiliki alur sejarah serta perkembangan yang spesifik atas jenis kegiatan seni itu (Kusrianto, Adi: 2009: 110)

Ilustrasi diperlukan untuk mewakili dan memperjelas teks yang ada pada buku dan memenuhi perancangan yang menarik perhatian. Selain itu, Ilustrasi dapat membantu cerita memvisualisasikan karakter pada sebuah teks atau menampilkan contoh item yang ada. Atau fungsi ilustrasi yang paling sederhana adalah membuat pembaca merasa trerhibur dengan teks yang didampingi oleh sebuah gambar.

Hal yang perlu diperhatikan dalam proses pembuatan ilustrasi pada sebuah desain terutama untuk perancangan buku, bukan hanya memperhatikan poin seberapa menariknya ilustrasi yang dimuat? Namun 'apakah ilustrasi tersebut sudah cukup memikirkan karakteristik target sasaran?', jika tidak maka bagaimana untuk menyampaikan pesan, kemungkinan terbesar adalah target sasaran malah sama sekali tidak tertarik dengan ilustrasi yang dimuat pada sebuah buku. Untuk itu pengolahan data sebelumnya penting diperhatikan untuk menciptakan sebuah ilustrasi yang efektif dan efisien.

“... displin ilmu ilustrasi akan terus berkembang mengikuti perkembangan dunia. Sebagai alat berkomunikasi, ilustrasi memiliki karakter yang harus dipahami agar pemanfaatan ilustrasi dapat memberikan efek yang diinginkan. Pengetahuan dan kreatifitas bersama dengan penguasaan teknis menjadi dasar dalam penciptaan karya ilustrasi. Saat sekarang ini aplikasi ilustrasi bisa kita lihat dimana-mana. Ilustrasi digunakan diberbagai alat visual komunikasi. Era digital memberikan kemudahan dalam hal teknis pembuatan ilustrasi, dunia internet memberikan kesempatan ekspos secara luas terhadap ilustrasi, para illustrator mendapatkan kesempatan begitu besar untuk dikenal secara luas. Oleh karena itu pemahaman akan sifat dan peran ilustrasi menjadi penting" (Witabora, 2012: 666)

Seiring berkembangnya teknologi, sifat dan peran ilustrasi menjadi semakin meningkat pula. Terdapat ilustrasi dimana-mana untuk diterapkan dalam 
kehidupan sehari-hari kemudian untuk membuatnya juga sudah banyak teknologi canggih yang mendukungnya. Teknologi tersebut mempermudah seseorang untuk menghasilkan dan meningkatkan kualitas ilustrasinya.

Buku Ilustrasi atau buku bergambar (Picture Book atau Illustrated Book) merupakan salah satu dari banyak jenis buku yang popular beredar di masyarakat luas. Buku ilustrasi atau buku bergambar merupakan buku yang menggabungkan tulisan/teks/narasi dengan gambar/ilustrasi/fotografi.

Ilustrasi/gambar pada buku memiliki kontribusi membuat buku menjadi lebih indah dan menyenangkan. Selain itu ilustrasi dalam sebuah buku juga mampu menarik perhatian, membabarkan cerita, mengajarkan konsep dan sebagai pengembang apresiasi dan kesadaran akan seni.

Dalam buku ilustrasi terjadi hubungan simbiotik antara gambar dan kata-kata. Ada berbagai macam pembagian dalam buku bergambar, selain buku cerita seperti fabel, legenda, mitos dan lainnya, juga ada jenis buku sains dan esiklopedia yang dikemas dalam bentuk ilmu pengetahuan populer. Buku ini memiliki cara penyampaian pesan secara visual yang berbeda dengan buku gambar lainnya, karena memberikan fakta dan perlu penyajian infographic yang sesuai dengan materi, tujuan dan target audiens.

\section{B. Metode Konsep Perancangan}

Konsep perancangan merupakan tahap lebih lanjut untuk membuat perencanaan-perencanaan berdasarkan analisa data yang sudah didapatkan sebelumnya. Tahap ini terbagi menjadi tiga pokok pembahasan diantaranya adalah perencanaan media, perencanaan kreatif dan perencanaan tata desain.

Pada tahap ini penulis akan merencanakan dan menentukan media-media yang digunakan untuk perancangan promosi buku ilustrasi "Just Do(odle) It!". Media yang digunakan adalah sebagai berikut Pre Media berupa Leaflet, Stiker, Poster (online dan offline).

Main Media berupa Leaflet, Stiker, Mug, Tumblr, Wadah Pensil, Tas Serut, Notebook, X-Banner, Key Chain, T-Shirt, Poster dan Booklet. Dan Follow Up Media berupa Social Media (Instagram), Sticker, Bookmark.

Tahap ini dilakukan lebih mendalam dan menuju ke inti sebuah proses perancangan. Selain itu penulis juga akan menentukan sejumlah formula untuk menghasilkan sebuah perancangan yang mampu menarik perhatian dan informatif. Berikut adalah penjelasan ketiga pokok bahasan dalam tahap perencanaan kreatif.

1. Pra Produksi

Pada tahap ini penulis akan menentukan ide dan konsep perancangan, kemudian mengumpulkan sejumlah data-data untuk diolah menjadi ilustrasi, headline, subheadline, body copy dan tagline.

2. Produksi

Pada tahap ini, sudah mulai memasuki pembuatan media, baik utama mauapun media pendukung. Datadata yang sudah rampung dan terkumpul diolah dan diaplikasikan ke berbagai media yang telah direncanakan.

3. Tahapan Akhir

Di tahap ini, media diperiksa kembali dan jika sudah benar-benar sesuai dengan standar maka akan dilakukan finishing seperti menggunting, menempel, melipat dan rendering.

Dalam perancangan ini akan menggunakan tata desain yang menarik dan tidak membosankan bagi pembaca/target sasaran. Untuk itu penulis akan memperhatikan setiap unsur dan tata letak pada buku ini. Ada beberapa hal penting yang mesti diperhatikan dalam perancangan buku ini seperti jenis huruf, spasi, warna dan elemen-elemen visual yang digunakan.

Metode ini memaparkan tahap pengolahan sejumlah data yang telah didapat menjadi sebuah bentuk/gambar. Berikut adalah penjelasan tahap-tahap yang dilakukan pada metode ini.

a. Layout gagasan/ide (idea layout/thumbnail)

Pada tahap ini penulis menyusun sebuah image board atau gagasan konsep visual yang dibutuhkan untuk perancangan.

b. Layout kasar (rough layout/tight tissue)

Pada tahap ini, mulai membuat beberapa alternatif sketsa layout yang sesuai dengan konsep kreatif.

c. Layout lengkap (comprehensive layout / execution / final design)

Membuat desain yang sesuai dengan sketsa yang telah dikerjakan sebelumnya sebagai hasil akhir.

\section{Pembahasan}

Doodle dikenal sebagai sebuah kegiatan mencoret pada sebuah media (baik itu kertas, kayu, tembok dan lain-lain). Mencoret merupakan hal yang dapat dilakukan oleh semua orang, tanpa mengenal waktu dan tempat. Biasanya hasil dari karya doodle terlihat abstrak karena dikerjakan secara spontan. Namun, ternyata ada pemahaman lain tentang doodle. Pemahaman tersebut malah menimbulkan kesan bahwa doodle merupakan sebuah gaya yang digunakan untuk menggambar berbagai objek untuk mengilustrasikan sesuatu, bahkan teks sekalipun. Terksesan rumit karena melalui beberapa tahap pada proses penggarapannya.

Objek yang terdapat pada doodle biasanya adalah sesuatu yang tidak nyata atau imajiner. Walaupun demikian, doodle yang bertema imajiner mampu merepresentasikan sebuah realita. Ada beragam alat yang bisa digunakan untuk membuat doodle, diantaranya adalah pena, pensil, spidol, krayon, cat air, dan lain-lain. Seiring berkembangnya teknologi, doodlepun dapat dikerjakan menggunakan sebuah alat bernama pen tablet yang terhubung pada pc/laptop.

Doodle memiliki banyak tema dan konsep, tergantung si pembuatnya. Ada yang tidak diwarnai dan ada pula yang diwarnai. Karena minimnya pengetahuan dan informasi mengenai doodle, terdapat sejumlah doodlers yang tidak memiliki karakter. Hal tersebut sangat dipenulisngkan, karena lambat laun orang tersebut 
akan merasa bosan dan tidak menemukan perasaan senang lagi ketika membuat doodle $\neg$.

Kata doodle pertama kali muncul pada awal abad ke17 berarti bodoh atau bodoh. Ini mungkin berasal dari Jerman atau Nudeltopf Dusseldorf, berarti bodoh atau mie (harfiah"minum-minum"). Makna "bodoh, bodoh" yang dimaksud dalam judul lagu "Yankee Doodle", awalnya dinyanyikan oleh pasukan kolonial Inggris sebelum Perang Revolusi Amerika. Ini juga merupakan asal dari kata kerja abad kedelapan belas dini untuk mencoret-coret, yang berarti "untuk menipu atau membodohi". Arti modern muncul pada 1930-an baik dari makna ini atau dari kata kerja "untuk berlamalama", yang sejak abad XVII telah memiliki makna membuang-buang waktu atau karena malas. Coretcoretan yang ditemukan dalam gua-gua zaman dulu itu salah satu gaya doodle tertua, bahkan sebelum orang mengenal tulisan, dimana doodling dijadikan alat untuk menceritakan sebuah kisah turun temurun. (http://www.desainstudio.com/2012)

Jika dilihat kisaran tahun 2012 hingga 2018, doodle dari yang hanya merupakan sebuah kegiatan mencoret berkembang menjadi sesuatu yang tidak hanya mencoret lagi. Terdapat sejumlah orang yang memanfaatkan doodle sebagai gaya menggambar yang mampu menyampaikan pesan.

\section{A. Konsep Perencanaan Media}

Tujuan dari Perancangan Buku Ilustrasi "Just Do(odle) It!" adalah dengan dibuatnya media utama sebuah buku sebagai sarana berkomunikasi. Diharapkan dapat mengedukasi dan memberi informasi kepada masyarakat terutama target sasaran tentang doodle. Media yang akan digunakan terdiri dari Pre media, Main media, dan follow up media.

Dari wawancara dan observasi data disimpulkan bahwa buku ini memiliki nilai pembelajaran yang dapat memberikan informasi dan pengetahuan tentang doodle. Masyarakat diajak untuk mengenal dan mengetahui doodle, buku ini dikemas dengan ilustrasi doodle beserta teks yang memberi tahu apa itu doodle, bagaimana cara membuat, sejarah singkat, dll.

Strategi kreatif dalam perancangan ini mencakup gagasan kreatif, tujuan kreatif, pesan verbal (Headline, Subheadline, Tagline/Slogan, dan Bodycopy), pesan visual (Figure, Object, Color, Typography), dan gaya tampilan desain.

Pada gagasan kreatif, perancang mengambil tema "membuat dan memahami doodle". Gagasan ini diambil dari banyaknya doodle yang bermunculan dan memiliki keseragama bentuk karya, sehingga doodlers sulit menemukan karakter barunya. Berdasarkan observasi yang dilakukan, ada beberapa informan yang menyebutkan bahwa doodle juga sangat potensial dan mampu menjadi sumber penghasilan, maka daripada itu penting untuk memuat sejumlah informasi dan pengetahuan tentang doodle. Big idea dari "Just Do(odle) It!" mengartikan bagaimana perancang mengajak masyarakat untuk mulai membuat doodle tanpa ragu dan segera mencari tahu informasi dan pengetahuan doodle untuk mengasah dan mengembangkan karyanya. Dengan adanya gagasan kreatif yang mendukung diharapkan doodlers dapat menemukan karakternya dan agar mendapatkan sejumlah keuntungan dari karya doodle.

Ide visual yang digunakan pada karya adalah karakter yang divisualkan dengan remaja yang menekuni doodle, unsur visual lainnya yang digunakan adalah perlengkapan untuk membuat doodle dan ornamenornamen abstrak yang digabungkan pada karakter yang telah disebutkan sebelumnya. Karakter utama tersebut bergender perempuan dan memiliki khayalan dan teman imajinasi yang divisualisasikan sebagai karakter pendukung. Ilustrasi yang digunakan di setiap halaman yang memuat teks mewakili teks yang ada. Ornamen abstrak dikerjakan secara spontan dan tidak memiliki bentuk yang menyerupai benda atau makhluk hidup.

Adanya tujuan kreatif untuk menggunakan gagasan "membuat dan memahami doodle" sebagai tema utama dalam perancangan ini adalah untuk mengajak membuat doodle serta mengenalkan dan memberitahu informasi dan pengetahuan tentang doodle. Pengelolahan gagasan kreatif akan menghasilkan upaya untuk membuka wawasan pengetahuan tentang seni rupa terutama doodle.

Dengan adanya headline pada Perancangan Buku Ilustrasi "Just Do(odle) It!" akan mampu menarik perhatian dari target sasaran. Headline yang digunakan pada adalah "Seluk Beluk Doodle".

Kalimat penjelas yang akan dimuat dalam Perancangan Buku Ilustrasi "Just Do(odle) It!" akan meningkatkan informasi mengenai apa yang telah disajikan kepada target sasaran. Subheadline yang digunakan pada perancangan ini adalah "Mengenal dan Memahami Doodle Lebih Dekat".

Tagline merupakan rangkaian dari kalimat pendek yang digunakan untuk mengasosiasikan sebuah brand di benak target sasaran. Sehingga, dalam Perancangan Buku Ilustrasi "Just Do(odle) It!" mampu mencapai tujuannya untuk mengingatkan. Adapun tagline dari perancangan ini adalah "Ayo mengenal dan memahami Doodle!"

Karakter utama adalah salah satu figur anggota komunitas yang cukup aktif. Figur ini digambarkan dengan seseorang yang bergender perempuan dikerjakan menggunakan gaya doodle.

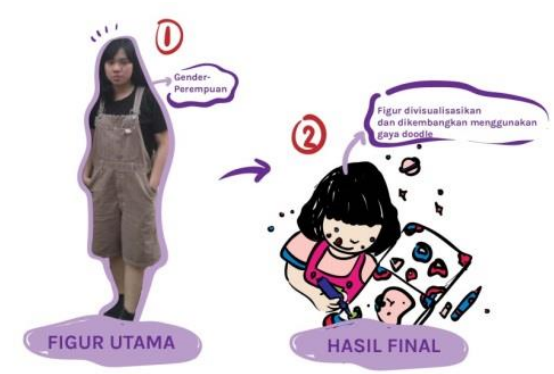

Gambar 1. Karakter Utama

Karakter pendukung merupakan teman-teman imajiner dari karakter utama digambarkan dengan 4 
orang remaja yang terdiri dari 2 laki-laki dan 2 perempuan.

Media periklanan yang berada di sekitar kita, meski kadang tanpa kita sadari selalu mengikuti aktifitas keseharian manusia (Viatra Aji Windu, 2017:2). Elemen yang digunakan pada Perancangan Buku Ilustrasi "Just Do(odle) It!" mengikuti aktifitas keseharian penggiat doodle yaitu menggunakan objek berupa alat tulis seperti pensil, pena, penggaris, buku gambar, kuas, pena, spidol. Selain itu akan ada banyak objek yang berbentuk abstrak karena mampu mencerminkan karakteristik doodle.

Konsep warna yang digunakan adalah warna-warna cerah. Pemilihan warna digunakan agar teks terbaca dengan jelas dan menarik perhatian target sasaran.
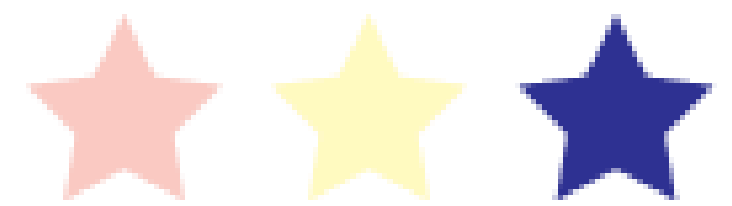

Gambar 2. Warna-warna yang mendominasi desain

Warna ini digunakan agar menambah kesan yang ceria dan menambah semangat pembaca. Efek yang bisa ditimbulkan oleh warna pastel adalah sejuk, nyaman, ceria, kalem dan lain lain. Semua tergantung kombinasi dan penempatan warnanya. Contohnya : ketika berada dalam ruangan yang memiliki kombinasi warna pastel, maka perasaan kita pasti akan nyaman dan ceria. Pengaruh ini akan membuat otak kita berkhayal tentang sesuatu tentang keceriaan.

Font yang digunakan pada perancangan buku ini adalah lovebuzz karena bentuknya yang hampir sama dengan line yang digunakan pada doodle agar tepat untuk buku ini, jenis huruf yang dirancang adalah sans serif dan bold.

\section{LOVEBUZZ \\ ABCDEFGHIJKLMNOPARSTUVWXYZ 0123456789 \\ Gambar 3. Font Judul}

Font nama pengarang menggunakan jenis huruf sans serif yang sudah tersedia di website. Font yang dipilih bernama "Karla (Bold)" Font nama pengarang menggunakan jenis huruf sans serif yang sudah tersedia di website. Font yang dipilih bernama "Karla (Bold)"

\section{A B C DEFGHIJKLMNOPQRSTUVWXYZ abcdefghijkImnopqrstuvwxyz 1234567890}

\section{Gambar 4. Font Nama Pengarang Konsep}

Gaya desain yang digunakan adalah desain yang dibuat dengan ilustrasi bergaya kontemporer. Gaya kontemporer mulai berkembang sekitar awal 1920-an yang dimotori oleh sekumpulan arsitektur Bauhaus School of Design di Jerman. Mereka merespon kemajuan teknologi dan perubahan sosial masyarakat akibat perang dunia. Gaya kontemporer dalam seni bangunan sendiri mulai berkembang pesat pada tahun 1940-1980an.

Di Indonesia istilah kontemporer pertama kali muncul di tahun 70'an. Tokoh yang pertama kali menggunakan istilah kontemporer adalah Gregorius Sidharta Soegijo (Yogyakarta, 30 November 1932 Surakarta, 04 Oktober 2006) untuk menamai karya seninya. Beliau adalah seniman yang berkecimpung di dunia seni patung dari indonesia, bahkan karya nya sudah mendunia salah satu karya nya yang terkenal ialah "Tangisan Dewi Betari” dan "Tonggak Samudra. Sejak saat itu istilah kontemporer banyak digunakan oleh Pematung Terkenal Asal Indonesia untuk menamai karya-karya mereka serta seringkali diperbarui dan disesuaikan dengan perkembangan yang ada.

Penerapan konsep layout yang digunakan pada perancangan buku "Just Do(odle) It!" adalah Eksplorasi Grid, yang artinya penulis akan merancang grid sesuai dengan kebutuhan dan tujuan dari desain. Dengan memodifikasi grid-grid standard yang sudah ada diharapkan dapat menciptakan sebuah desain layout yang lebih dinamis dan artistik.

Ilustrasi akan dikerjakan dengan menggunakan sketsa awal menggunakan pensil kemudian akan di-scan dan diolah menggunakan software dengan menggunakan teknik vector dan digital painting. Jenis doodle art yang dipakai pada perancangan ini adalah planned doodle art. Perancangan buku ilustrasi "Just Do(odle) It!" hanya memiliki satu seri saja.

\section{B. Final Desain}

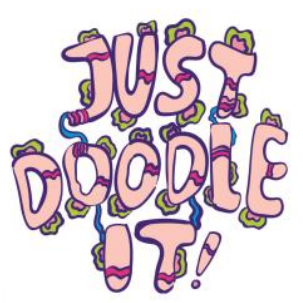

Gambar 5. Logo

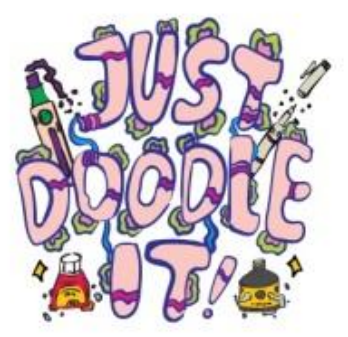

Gambar 6. Alternatif Logo 


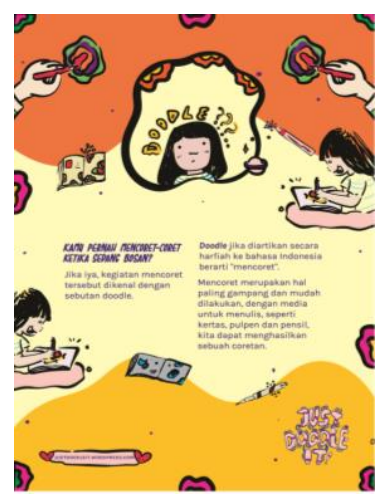

Gambar 7. Poster Pengertian Doodle

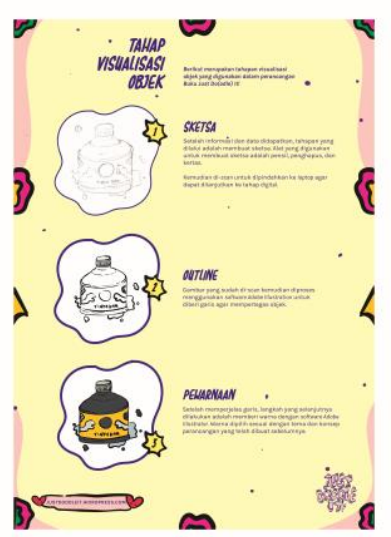

Gambar 8. Poster Tahap Visualisasi Objek

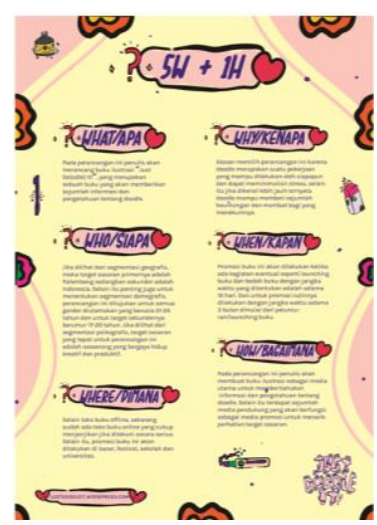

Gambar 9. Poster 5W 1H

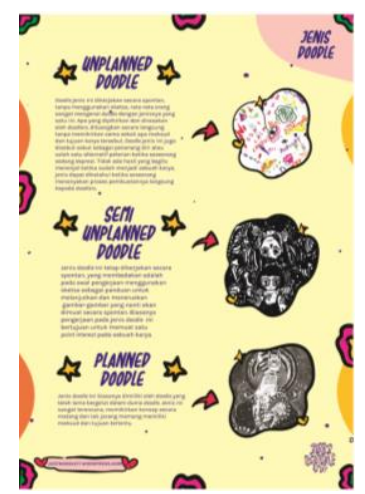

Gambar 10. Poster Jenis Doodle

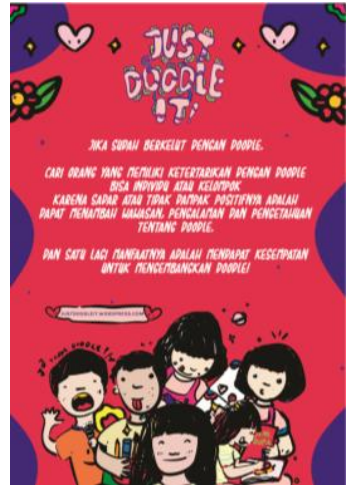

Gambar 11. Poster Quotes

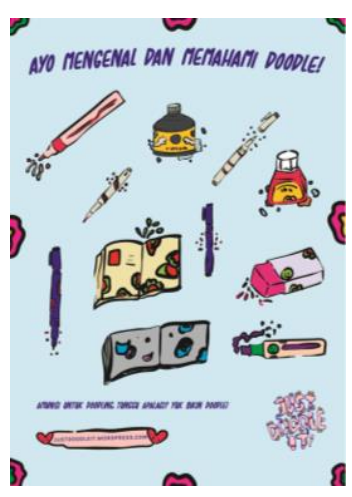

Gambar 12. Poster Kits

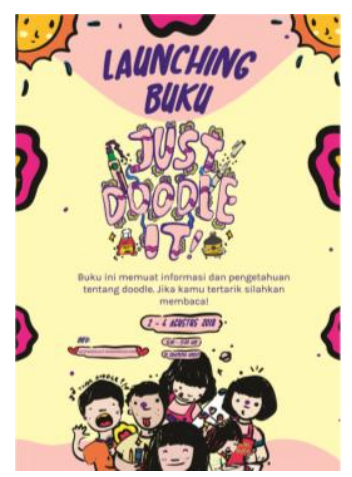

Gambar 13. Poster Promosi

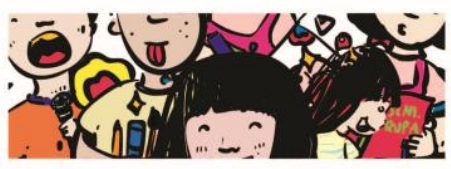

Gambar 14. Stiker Karakter

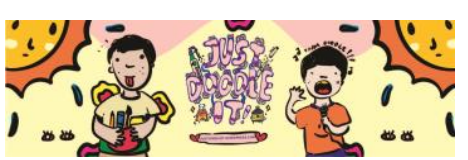

Gambar 15. Pembatas Buku 


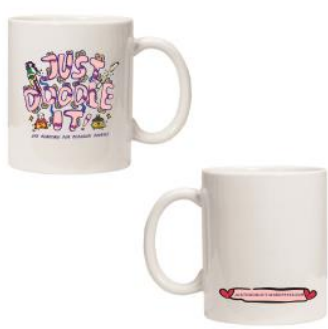

Gambar 16. Mug

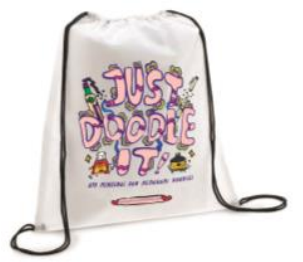

Gambar 17. Tas Serut Logo

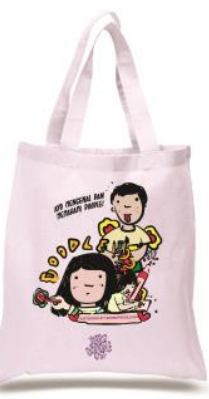

Gambar 18. Totebag Karakter

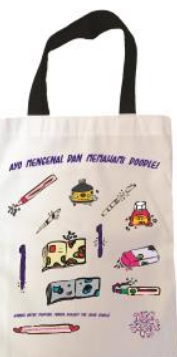

Gambar 19. Totebag Kits

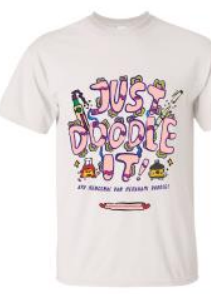

Gambar 20. T-Shirt Logo

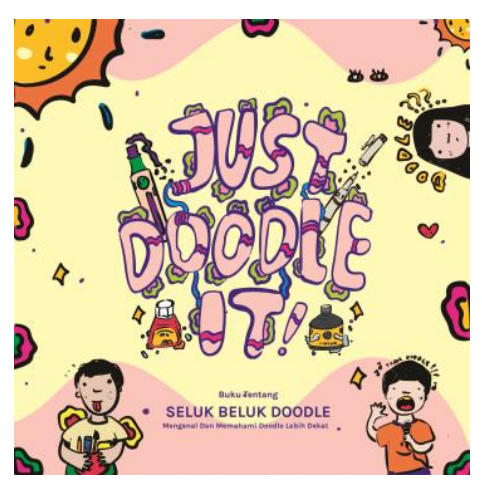

Gambar 21. Sampul Depan Buku

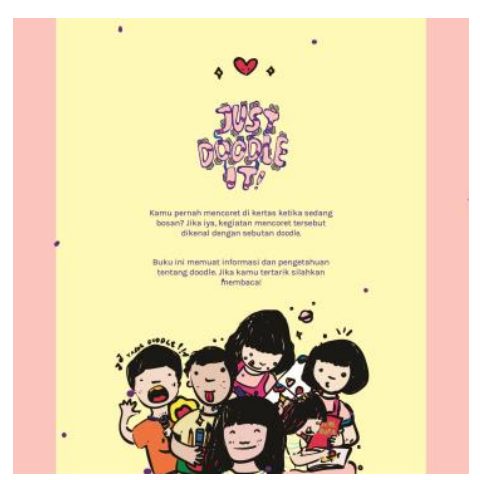

Gambar 22. Sampul Belakang Buku

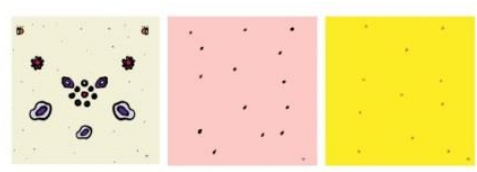

Gambar 23. Jeda Halaman Buku

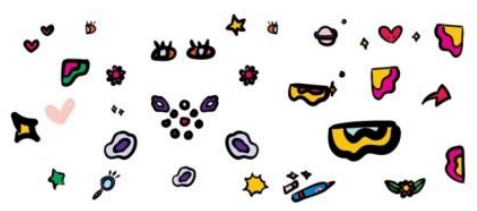

Gambar 24. Ornamen Buku

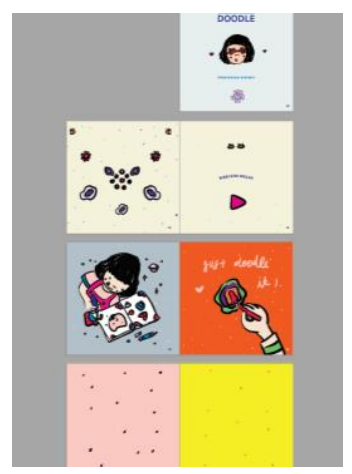

Gambar 25. Buku Halaman 3-9 


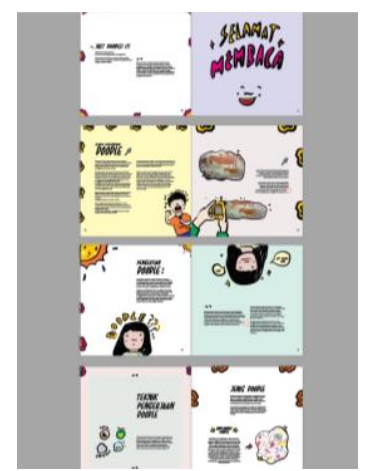

Gambar 26. Buku Halaman 18-25

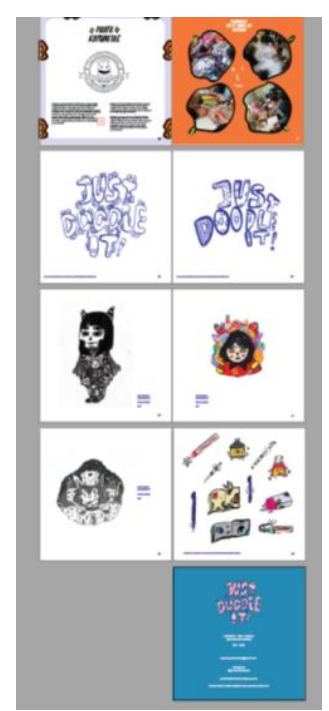

Gambar 27. Buku Halaman 26-34

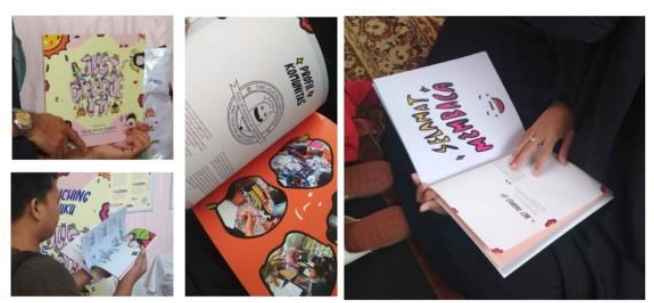

Gambar 28. Buku Ilustrasi “Just Do(odle) It!"

\section{Kesimpulan}

Doodle merupakan kegiatan mencoret yang akhirnya berkembang menjadi sebuah gaya dalam membuat sebuah karya seni rupa. Untuk pengerjaannya dilakukan secara spontan atau terkonsep. Permasalahan utama yang ditemukan dari doodle adalah tidak ditemukan informasi dan pengetahuan tentang doodle. Banyak sekali manfaat dan keuntungan dari doodle diantaranya adalah mampu menambah pemasukan ekonomi bagi yang menekuninya. Untuk menekuni doodle seseorang harus bisa menemukan karakter dari karyanya. Karya yang berkarakter maksudnya adalah memiliki objek-objek yang konsisten di setiap karya. Untuk memiliki karya yang berkarakter selain harus terus produktif berkarya, mesti memiliki sumber pengetahuan dan informasi. Proses perancangan yang dilakukan adalah dengan cara menemukan permasalahan dari doodle itu sendiri dengan melakukan observasi, wawancara, buku serta internet. Kemudian membuat mind mapping untuk membantu proses perancangan dan menemukan konsep. Setelah data dikumpulkan maka akan disusun menggunakan tata letak yang menarik dan informatif. Dari perancangan yang sudah dilakukan, dapat disimpulkan akan berguna bagi masyarakat ataupun target sasaran agar dapat mengenal dan memahami serta mendapat informasi dari buku ilustrasi tentag doodle. Dengan menggunakan media utama buku dan berbagai media pendukung lainnya diharapkan pesan dapat tersampaikan dengan tepat sasaran. Selain itu dengan adanya buku ini diharapkan setiap doodlers yang belum percaya diri untuk memulai doodle diharapkan dapat memulai membuat dan menciptakan karakter hingga dapat menghasilkan banyak keuntungan dari doodle.

\section{Daftar Pustaka}

Anggraini \& Nathalia, K. 2014. Desain Komunikasi Visual: Dasar-Dasar Panduan untuk Pemula, Bandung: Nuansa Cendekia. Bohang, Lala. 2017. The Book of Invisible Questions, Jakarta: PT. Gramedia Pustaka Utama.

Darsono, Sony Kartika. 2017. Seni Rupa Modern: Edisi

Revisi, Bandung: Rekayasa Sains. 2007. Estetika, Bandung: Rekayasa Sains.

Sanyoto, Sadjiman Ebdi. 2010. Nirmana: ElemenElemen Seni dan Desain, Jilid II. Yogyakarta: Jalasutra.

Kasali, Rhenald. 1995. Manajemen Periklanan: Konsep dan Aplikasinya di Indonesia, Jakarta: PT. Pustaka Utama Grafiti.

Kusrianto, Adi. 2009. Pengantar Desain Komunikasi Visual, Jilid II, Yogyakarta: Penerbit ANDI.

Mustar, Reza. 2016. POP! Art Coloring Book That Pops: Suddenly, Unexpectedly, Jakarta: PT. Gramedia Pustaka Utama.

Rosanes, Kerby. 2015. Animorphia: Buku Mewarnai Penuh Tantangan, PT. Jakarta: Gramedia Pustaka Utama.

Santo, Agung dkk. 2012. Menjadi Seniman Rupa, Bandung: Metagraf.

Suharso \& Retnoningsih, Ana. 2012. Kamus Besar Bahasa Indonesia: Edisi Lux, Semarang: Widya Karya. Suryajaya, Martin. 2016. Sejarah Estetika: Era Klasik

Sampai Kontemporer, Yogyakarta: Gang Kabel.

Tinarbuko, Sumbo. 2015. DE KA VE: Desain Komunikasi Visual, Penanda Zaman Masyarakat Global, Yogyakarta: Center for Academic Publishing Service.

Viatra, Aji Windu. 2017. Besaung: Jurnal Seni Desain dan Budaya Volume 2 No.1, Palembang : Universitas Indo Global Mandiri 